\title{
Antioxidant activity, sensory analysis and acceptability of red fruit juice supplemented with Brazilian green propolis
}

\author{
Géssica Aparecida LOPES ${ }^{1}$, Priscila Cardoso FIDELIS ${ }^{1}$, Bruno Moura de ALMEIDA², Jane José ALMEIDA², \\ Gislaine de Almeida Santana IENTZ ${ }^{3}$, Nancy Scardua BINDA ${ }^{4}$, Arthur Ferrari TEIXEIRA ${ }^{5}$, \\ Sidney Augusto VIEIRA-FILHO ${ }^{5}$ (D), Rachel Basques CALIGIORNE, Dênia Antunes SAÚDE-GUIMARÃES ${ }^{4,5}$, \\ Maria Helena Nasser BRUMANO ${ }^{1}$, Sônia Maria de FIGUEIREDO ${ }^{1,6 *}$ (D)
}

\begin{abstract}
In this work were determining the total phenolic content, total flavonoids and antioxidant capacity in formulations of red fruit juice supplemented with different concentrations of aqueous extract of Brazilian green propolis. And, also was investigate the formulation sensory acceptance by volunteers' consumers. The addition of propolis to red fruit juice increased the content of total phenolic compounds and flavonoids, enhanced the antioxidant activity of the final product as assessed by radical scavenging DPPH and ABTS and FRAP methods, and no negative effect on consumer taste. All red fruit juice formulations containing propolis presented significant results through overall acceptability test and were approved in relation to purchase intent by the volunteer consumers. Formulation F3 $\left(6.1 \mathrm{mg} \cdot \mathrm{mL}^{-1}\right)$ showed the best results. The antioxidant activity increment was proportional to the concentration of aqueous green propolis extracts added to the juice. The positive purchase intention reached up $64.75 \%$ of participants' acceptance. A new, sugar-free drink with pleasurable sensory and functional properties, combined with health benefits, has been obtained.
\end{abstract}

Keywords: red fruit juice; green propolis; antioxidant capacity; sensory evaluation; purchase intention.

Practical Application: Antioxidative and sensory analysis of red fruit juice formulated with Brazilian green propolis.

\section{Introduction}

The increase in people's life expectancy has standing out concomitantly with the increased incidence of diabetes, hypertension, cancer and other chronic diseases. Because of this, many people have been adopting healthier eating habits, correlating it to the adoption of a more balanced diet (de Andrade Lopes et al., 2020; Ferreira et al., 2019; Vidal et al., 2012). It is recommended to include functional foods in healthy eating habits.

Foods with functional properties are those that have properties related to the metabolic or physiological role a substance has in growth, development, maintenance of normal functions of the human body. Functional foods are rich in flavonoids, phenolic compounds and other bioactive compounds, which act positively on one or more physiological functions of the body. Because of this, functional foods have aroused the interest of the scientific community because of their health benefits and because they also represent a promising market. Bioactive compounds are responsible for an improvement in health and the quality of life and contribute for the reduction of the risks of diseases, especially the non-communicable diseases (Altemimi et al., 2017; Costa
\& Rosa, 2016; Dranca \& Oroian, 2016; Manubolu et al., 2014; Stringueta et al., 2012; Vetrani et al., 2013). In this context, products with functional properties have being considered a new trend in the food market which aim to attend those seeking healthier foods. Thus, it is important to have bioactive compounds inserted as ingredients in the formulation of functional and nutraceutical foods (Bezerra et al., 2017; Silva et al., 2016).

Propolis or bee glue is a highlighted product among those with functional properties. Propolis is a resinous mixture that honeybees produce by mixing saliva and beeswax with exudate gathered from tree buds, sap flows, or other botanical sources, to seal honeycomb. Among the different types of propolis, the Brazilian green propolis is considered one of the most important due to its chemical constitution (de Figueiredo et al., 2014). Baccharis dracunculifolia, popularly known as "Alecrim do Campo" or "Vassourinha", found in the southeast region of Brazil, mainly in the state of Minas Gerais and São Paulo, is the main plant used by bees as source of substances for the production of green propolis (Arruda et al., 2020; Ferreira \& 
Negri, 2018). The green propolis contains a significant amount of artepellin C, a derivative of cinnamic acid, which is responsible for several properties, such as anti-inflammatory, antimicrobial, antifungal, anticancer and antioxidant activity (Gregolin et al., 2019; Hochheim et al., 2019; Sousa et al., 2019; Galeotti et al., 2018; Bittencourt et al., 2015).

Despite of the benefits that the consumption of propolis bring to the consumers and the great interest in enriching food and beverages, the use of propolis is limited and its acceptability is low due to its unpleasant sensory characteristics, such as bitter taste and strong odor (Jansen-Alves et al., 2018; Osés et al., 2016). In order to increase propolis consumption, honey has been enriched with small amounts of propolis extracts, making enriched honey a promising functional food (Juszczak et al., 2016; Osés et al., 2016).

Red fruits present attractive colors and are tasty, therefore have sensory characteristics that attracts the consumer, and are important dietary sources of flavonoids, flavonols, phenolic acids, tannins, stilbenes, anthocyanins and other bioactive compound (Kubota et al., 2012; Bermúdez-Soto \& Tomás-Barberán, 2004). Juices made from red fruit blends are already available on the markets and offer new flavors to their consumers (da Cruz Almeida et al., 2017).

A possible way to increase propolis intake would be to incorporate it into a product of high-frequency consumption by the population, such as fruit juices. Propolis has been used as a natural additive agent in orange juice as an alternative to chemical preservatives (Yang et al., 2017; Luis-Villaroya et al., 2015). Thus, the addition of green propolis in fruit juice consists of an alternative way to enhance its intake, offering to the consumers an adequate nutritional content, rich in bioactive and antioxidant compounds, and with a pleasant sensorial characteristic. To meet this expectation, the objectives of present study were: i) obtain a drink supplemented with Brazilian green propolis, from a red fruits juice commercially available; ii) determining the total phenolic content, total flavonoids and antioxidant capacity of the resulting beverage; iii) conducting a study of the sensory properties of this beverage in terms of its acceptability and purchase intention.

\section{Material and methods}

\subsection{Chemicals and general procedures}

Quercetin, gallic acid and Trolox standards were purchased from Sigma-Aldrich. The reagents Folin Ciocateu (Dinâmica Quimica Contemporânea Ltda) and aluminum chloride hexahydrate (LabSynth) were used to determine phenolic and flavonoid compounds, respectively. For antioxidant capacity analysis, the reagents ABTS (2,2'-azino-bis-(3-ethylbenzothiazoline-6sulfonic acid), DPPH (2,2-diphenyl-1-picrilhhydrazyl), TPTZ (2,4,6-Tris(2-pyridyl)-s-triazine) and Trolox (6-hydroxy-2,5,7,8tetramethyl chromane 2-carboxylic acid) were obtained from Sigma-Aldrich. All reagents and solvents used were of analytical grade purity. All absorbance determinations of the samples were measured on a UV-Visible Digital Spectrophotometer (Model GTA-97).

\subsection{Acquisition of samples}

The samples of a red fruit juice, Campo Largo (Lot L9084), were provided by Empresa Zanlorenzi Bebidas, located in the city of Campo Largo, Paraná, Brazil. Samples of aqueous green propolis extract, (Lot PWE0219), were supplied by Pharmanectar, located in the Caeté Municipality, Minas Gerais, Brazil.

\subsection{Green propolis characterization by planar chromatography}

\subsubsection{Preparation of sample}

The fresh green propolis $(1.0 \mathrm{~g})$ was macerated in $100 \mathrm{~mL}$ of ethanol $85 \%(\mathrm{v} / \mathrm{v})$, and filtered on filter paper to obtain its ethanolic extract. Ethanolic and aqueous green propolis extracts were diluted to $10 \%\left(\mathrm{v}^{-1}\right)$ in ethanol $85 \%$ and water, respectively. Ethanolic (S1 and S2) and aqueous (S3) extracts of green propolis samples were characterized by thin-layer chromatography (TLC) in parallel with artepilin C, considered to be one of the main components of Brazilian green propolis (de Figueiredo et al., 2014). The samples $(5 \mu \mathrm{L})$ were applied to Biotage ${ }^{\oplus}$ KP-SIL silica gel chromatoplates $(10 \times 10 \mathrm{~cm})$ and eluted with chloroform-ethyl acetate $\left(55: 45 \mathrm{v}^{\mathrm{v}} \mathrm{v}^{-1}\right)$. First, the spots were visualized by exposing the plates under ultraviolet (UV) light at $254 \mathrm{~nm}$ using a Blak-Ray ultraviolet lamp. Then, for detection of phenols, flavonoids and other compounds, the chromatoplates were sprayed with a solution of freshly prepared $0.5 \mathrm{~mL}$ p-anisaldehyde in $50 \mathrm{~mL}$ glacial acetic acid and $1 \mathrm{~mL}$ $97 \%$ sulfuric acid, and heat to $105^{\circ} \mathrm{C} / 15 \mathrm{~min}$ for maximum visualization of spots.

\subsection{Formulations of beverage containing green propolis}

The red fruit juice used to prepare the propolis beverage formulations contained the following ingredients, declared on the label: whole grape juice, açai (Euterpe oleraceae M.) pulp (medium), concentrated juices of cranberry (Vaccinium macrocarpon Aiton), pomegranate (Punica granatum L.), plum (Prunus domestica L.), strawberry (Fragaria ananassa (Duchesne ex Weston) Duchesne ex Rozier), water and red fruit flavoring. The formulations of the supplemented beverage were elaborated with red fruit juice, xylitol and aqueous green propolis extract in three different concentrations of propolis. Based on the density $\left(1.15 \mathrm{~g} \cdot \mathrm{mL}^{-1}\right)$ of aqueous extract of green propolis, the supplemented red fruit juices formulations were prepared with the following final concentration of propolis: $\mathrm{F} 1=3.1 \mathrm{mg} \cdot \mathrm{mL}^{-1}$, $\mathrm{F} 2=4.6 \mathrm{mg} \cdot \mathrm{mL}^{-1}$ and F3 $=6.1 \mathrm{mg} \cdot \mathrm{mL}^{-1}$. The content of total phenolics, total flavonoids and antioxidant capacity were determined for the aqueous extract of green propolis, red juice fruit and for the beverage formulations F1 to F3.

\subsection{Determination of total phenolics and total flavonoids content}

Total phenolic compounds were determined using the Folin-Ciocalteu method (Singleton \& Rossi, 1965). Thus, $0.25 \mathrm{~mL}$ of the sample, adequately diluted, was transferred to test tubes and $1.25 \mathrm{~mL}$ of Folin-Ciocalteu reagent diluted in 
distilled water (1:10; v. $\left.\mathrm{v}^{-1}\right)$ was added. After $3 \mathrm{~min}, 1 \mathrm{~mL}$ of $7.5 \%$ sodium carbonate solution $\left(\mathrm{w} . \mathrm{v}^{-1}\right)$ was added and the mixture incubated for $1 \mathrm{~h}$ the absence of light, at room temperature. After $1 \mathrm{~h}$ in a dark, the absorbance at $760 \mathrm{~nm}$, using distilled water as a blank was measured. Based on a gallic acid calibration curve ( 0.005 to $\left.0.0625 \mathrm{mg} \cdot \mathrm{g}^{-1}\right)$, the content of phenolic compounds was expressed as gallic acid equivalent (GAE) in mg per gram $\left(\mathrm{mg}\right.$ GAE. $\left.{ }^{-1}\right)$ for green propolis aqueous extract and in $\mathrm{mg}$ per 100 grams (mg GAE. $100 \mathrm{~g}^{-1}$ ) for red fruit juice or beverage formulation F1 to F3.

The total flavonoid content was determined using the method described by Woisky and Salatino (1998) with modifications. The flavonoid compounds were extracted from aqueous extract of green and from juice formulations adding $10 \mathrm{~mL}$ of $0.2 \mathrm{~mol} . \mathrm{L}^{-1} \mathrm{HCl}$ to $1.0 \mathrm{~g}$ of the sample. After $10 \mathrm{~min}$ the material was macerated, filtered on quantitative filter paper (UniFil C40) and had its volume readjusted with methanol. Subsequently, appropriately diluted aliquots of the samples were added to an equal volume of $5 \%$ methanolic aluminum chloride solution $\left(\mathrm{w} . \mathrm{V}^{-1}\right)$ and after $30 \mathrm{~min}$, the reading was performed at $420 \mathrm{~nm}$. The aluminum chloride solution was replaced by methanol and used as the blank. The flavonoid content was determined by using a quercetin standard curve $\left(0.0025\right.$ to $\left.0.025 \mathrm{mg} \cdot \mathrm{g}^{-1}\right)$ and the results expressed in quercetin equivalent $(\mathrm{QE})$ in $\mathrm{mg}$ per

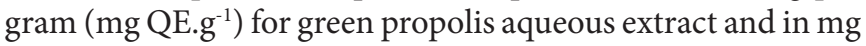
per 100 grams (mg QE. $100 \mathrm{~g}^{-1}$ ) for red fruit juice or beverage formulation F1 to F3.

\subsection{Determination of antioxidant capacity}

The antioxidant capacity of aqueous extract of green propolis, red fruit juice and of the beverage formulations containing propolis was carried out by means of radical scavenging assays DPPH and ABTS and by FRAP (Ferric Reducing Antioxidant Power) method.

The determination of the antioxidant capacity of the samples using DPPH assay was performed as state by Rufino et al. (2007). Aliquots of the sample solutions, appropriately diluted, were added to test tubes containing $1.95 \mathrm{~mL}$ of the $0.06 \mathrm{mmol} . \mathrm{L}^{-1} \mathrm{DPPH}$ solution. A control was performed replacing the same sample volume by $80 \%$ ethanol. After $30 \mathrm{~min}$ of reaction, the absorbance reading was performed at $517 \mathrm{~nm}$. The capability to scavenge the DPPH radical was calculated using the following equation: $\mathrm{DPPH}$ scavenged $(\%)=[(\mathrm{AB}-\mathrm{AA}) / \mathrm{AB}) \times 100]$, where, $\mathrm{AB}$ is absorbance of blank at $t=0 \mathrm{~min}$; $\mathrm{AA}$ is absorbance of the antioxidant at $\mathrm{t}=30 \mathrm{~min}$. A calibration curve was plotted with $\%$ DPPH scavenged versus concentration of standard antioxidant Trolox $\left(0.025\right.$ to $\left.0.900 \mu \mathrm{mol} . \mathrm{g}^{-1}\right)$. The results were expressed as $\mu \mathrm{mol}$ Trolox equivalent antioxidant capacity (TEAC) per gram $\left(\mu \mathrm{mol} \mathrm{TEAC.g^{-1 }}\right)$ for green propolis aqueous extract and $\mu \mathrm{mol}$ TEAC per 100 grams ( $\mu$ mol TEAC. $\left.100 \mathrm{~g}^{-1}\right)$ of red fruit juice or beverage formulation F1 to F3.

Antioxidant capacity of samples was also evaluated using ABTS as the source of free radicals (Re et al., 1999). Firstly, $7 \mu \mathrm{mol} . \mathrm{L}^{-1}$ of ABTS was reacted with $2.45 \mu \mathrm{mol} . \mathrm{L}^{-1}$ of potassium persulfate for $16 \mathrm{~h}$, in the dark, at room temperature. Then, the
ABTS radical was diluted with ethanol $80 \% \mathrm{v} / \mathrm{v}$ until absorbance $0.700 \pm 0.05$ at $734 \mathrm{~nm}$ and a volume of $2.5 \mathrm{~mL}$ was mixed with each sample. After $6 \mathrm{~min}$, the reduction of absorbance at $734 \mathrm{~nm}$ in the presence of the samples was measured. As control, the sample volume was replaced by distilled water. The scavenge capacity was determined using the following equation: ABTS scavenged $(\%)=[(\mathrm{AB}-\mathrm{AA}) / \mathrm{AB}) \times 100]$, where, $\mathrm{AB}$ is absorbance of blank at $\mathrm{t}=0 \mathrm{~min}$; AA is absorbance of the antioxidant after 6 min. A calibration curve was plotted with \% ABTS radical scavenged versus concentration of standard antioxidant Trolox $\left(0.025\right.$ to $\left.0.700 \mu \mathrm{mol} . \mathrm{g}^{-1}\right)$. The results were expressed as $\mu \mathrm{mol}$ TEAC per gram $\left(\mu \mathrm{mol}\right.$ TEAC. $\left.{ }^{-1}\right)$ for green propolis aqueous extract and $\mu \mathrm{mol}$ TEAC per 100 grams $\left(\mu \mathrm{mol}\right.$ TEAC. $\left.100 \mathrm{~g}^{-1}\right)$ of red fruit juice or beverage formulation F1 to F3.

The antioxidant capacity by the FRAP method was determined according to Rufino et al. (2006). The FRAP solution was obtained by combining $20.8 \mathrm{~mL}$ of $0.3 \mathrm{~mol}^{-\mathrm{L}^{-1}}$ acetate buffer, $2.1 \mathrm{~mL}$ of a solution of $10 \mathrm{mmol} . \mathrm{L}^{-1} \mathrm{TPTZ}$ and $2.1 \mathrm{~mL}$ of a $20 \mathrm{mmol} . \mathrm{L}^{-1}$ aqueous solution of ferric chloride. Aliquots of the sample solutions, properly diluted, were added to test tubes, containing $1.8 \mathrm{~mL}$ of the FRAP solution and $0.18 \mathrm{~mL}$ of distilled water, and placed in a thermostatic bath at $37{ }^{\circ} \mathrm{C}$ for $30 \mathrm{~min}$. After the reaction time, the absorbance of samples was determined at $595 \mathrm{~nm}$. A calibration curve was plotted with absorbance of FRAP versus concentration of standard antioxidant Trolox $\left(0.100\right.$ to $\left.0.900 \mu \mathrm{mol} . \mathrm{g}^{-1}\right)$. The results of antioxidant capacity values for FRAP were expressed as $\mu \mathrm{mol}$ Trolox equivalent antioxidant capacity (TEAC) per gram ( $\mu \mathrm{mol}$ TEAC. $\left.\mathrm{g}^{-1}\right)$ for green propolis aqueous extract and $\mu \mathrm{mol}$ TEAC per 100 grams $\left(\mu \mathrm{mol}\right.$ TEAC. $\left.100 \mathrm{~g}^{-1}\right)$ of red fruit juice or beverage formulation F1 to F3.

\subsection{Sensorial analysis}

The sensorial evaluation of red juice formulations was divided into two sessions. At the first session, 102 untrained voluntary tasters performed a blind test, with samples of the juice formulations F1 to F3. For each sample, $20 \mathrm{~mL}$ of the red juice containing propolis were offered in plastic cups encoded with random numbers. Water was served as a taste cleaner between samples. Consumers received acceptance test assessment sheets for each formulation. The acceptability of formulations in relation to its sensory attributes was assessed using a 9-point hedonic scale, which ranges from extremely dislike (1) to extremely like (9) (Lim, 2011). In addition, the purchase intention of the three red juice formulation was evaluated using a scale that varies from 1 (certainly would not buy) to 5 (certainly would buy). Subsequently, a second session of sensory analysis was carried out, where the tasters received an informative card with the information about the health benefits of propolis and red fruits. Right after the reading, the same samples of the red juice formulation, with different and random codes, was offered and the acceptability of formulations and purchase intention were determined as previously described (Vidigal et al., 2011). The study protocol was previously approved (Protocol number: CAAE $\mathrm{n}^{0}$ 14919519.6.0000.5150) by the Research Ethics Committee of Universidade Federal de Ouro Preto, Minas Gerais, Brazil. 


\subsection{Data analysis}

Data are presented as the mean value and standard deviation (SD) of three independent measurements. The significance of the results was assessed by analysis of variance (ANOVA). In case of statistical difference $(\mathrm{p}<0.05)$, the Tukey test was employed to assess the differences between medium or Dunnett procedure was applied to compare each formulation with the control juice. A paired t test was employed to compare the means obtained in the two sessions of sensory analysis. All statistical analyzes were performed at a 5\% significance level, using the software R.

\section{Results and discussion}

\subsection{Characterization of the aqueous extract of green propolis}

The quality of green propolis as well as its biological activity are correlated with its chemical constitution (de Figueiredo et al., 2014). Moreover, it seems consensus that the pharmacological action of green propolis happens due to the presence of flavonoids and also to the synergism between its chemical constituents (Toreti et al., 2013; Nunes et al., 2009; Lustosa et al., 2008). For this reason, it was performed an analysis by TLC of the aqueous extract, ethanolic extract, both of green propolis, in parallel with artepillin C (Figure 1). This prenylated derivative of $\mathrm{p}$-coumaric acid has being considered one of the principal phenolic compounds found in Brazilian green propolis and its botanical source Baccharis dracunculifolia (Shahinozzaman et al., 2020). The pharmacological properties of artepillin $C$ include antioxidant, antimicrobial, anti-inflammatory, anti-diabetic, neuroprotective, gastroprotective, immunomodulatory, and anti-cancer activities (Shahinozzaman et al., 2020). The presence of artepillin C in the Brazilian green propolis used for the red fruit juice supplementation was confirmed through TLC. The artepillin
$\mathrm{C}$ was detected ( $\mathrm{Rf} 0.58$ ) even in an aleatorily diluted sample (S3) (Figure 1). TLC performed with artepillin C standard can be considered as a good, easily performed technique, suitable for the substantiation of Brazilian green propolis.

The total phenolic content (41.38 mg GAE. $\mathrm{mL}^{-1}$ ) found for the aqueous green propolis extract used in the experiments

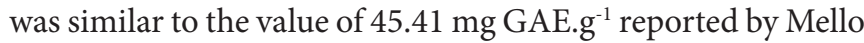
and Hubinger (2012). Values ranging from 31.85 to $67.42 \mathrm{mg}$ GAE. $\mathrm{g}^{-1}$ have already been described for Brazilian propolis extracts (Franz et al., 2018; Costa \& Rosa, 2016; Bittencourt et al., 2015). These values were higher than those found by Alves and Kubota (2013) and Hochheim et al. (2019), 5.39 and $11.96 \mathrm{mg}$ GAE. $g^{-1}$ respectively, for aqueous propolis extracts. The specie of bee, environmental conditions, climatic variations, type of local vegetation and extraction methods are some factors that directly influence the chemical constitution of propolis (Hochheim et al., 2019; Andrade et al., 2017; de Figueiredo et al., 2014).

The total flavonoid content found for the analyzed aqueous green propolis $\left(2.32 \mathrm{mg} \mathrm{QE.}{ }^{-1}\right)$ is within the range of values of $0.37 \mathrm{mg}$ QE.g ${ }^{-1}$ (Franz et al., 2018) to $16.30 \mathrm{mg}$ QE.g ${ }^{-1}$ (da Costa et al., 2016), for propolis from Pantanal region and Roraima state, Brazil, respectively. A flavonoid content of $3.67 \mathrm{mg} \mathrm{QE.g}^{-1}$ was reported by Hochheim et al. (2019) for aqueous extract of propolis produced in the South of Brazil by Brazilian native bee Melipona quadrifasciata.

The antioxidant capacity determined for the green propolis aqueous extract used to prepare red fruit formulations was $74.12 \mu \mathrm{mol} \mathrm{TEAC.g}{ }^{-1}$ (DPPH), $139.52 \mu \mathrm{mol} \mathrm{TEAC.g}{ }^{-1}$ (ABTS) and $113.40 \mu \mathrm{mol}$ TEAC.g ${ }^{-1}$ (FRAP). Similar antioxidant capacity results were found in ethanolic propolis extracts by da Costa et al. (2016) (27.01 to $85.89 \mu \mathrm{mol} \mathrm{TEAC.g}{ }^{-1}$ ) and
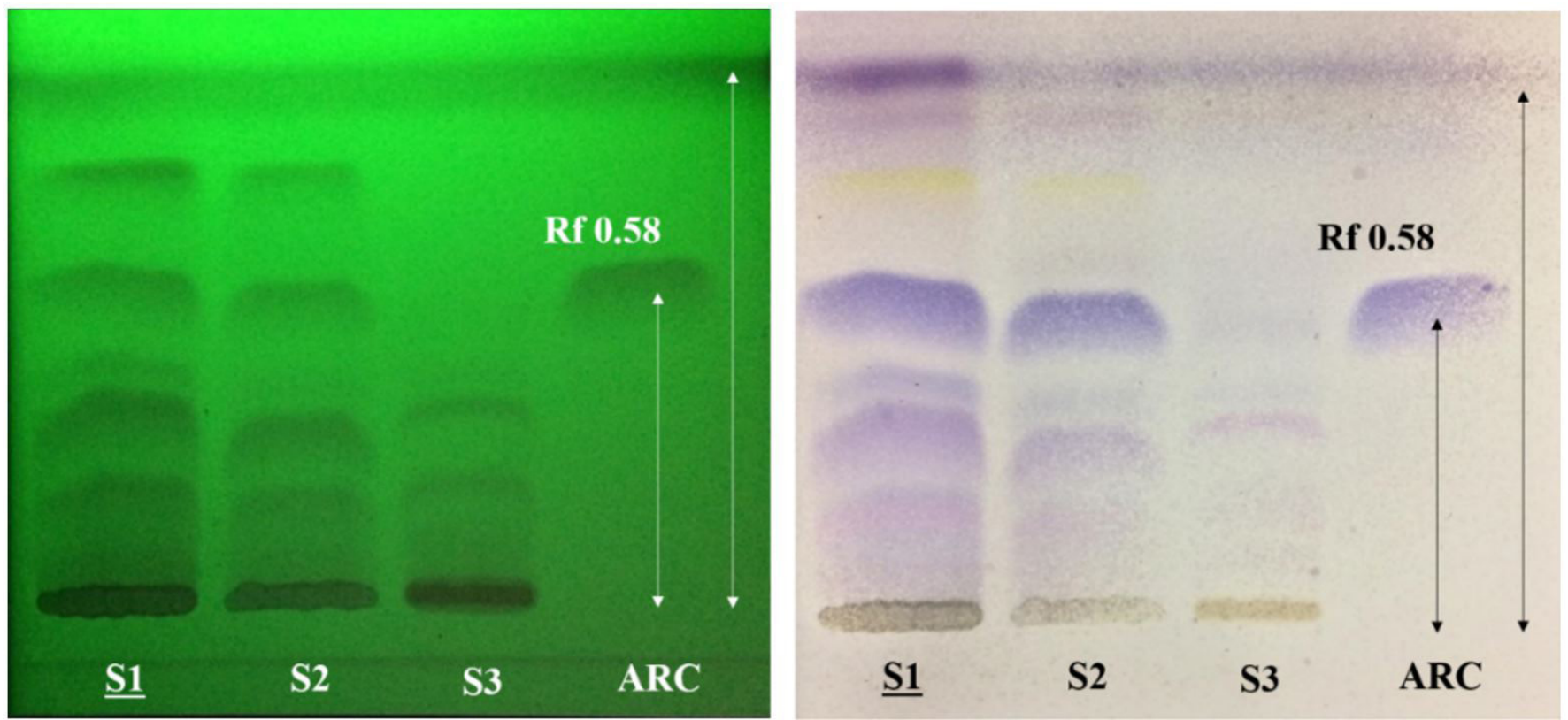

Figure 1: Silica gel thin layer chromatography of green propolis samples [ethanolic (S1 and S2) and aqueous (S3) extracts] in comparison to artepillin C (ARC) standard. Mobile phase: chloroform-ethyl acetate (55:45 v/v). Plate under UV light at $254 \mathrm{~nm}$ (Left), and after spraying with p-anisaldehyde-sulfuric acid solution, drying at $105^{\circ} \mathrm{C} / 15 \mathrm{~min}$, observed under visible light (Right). 
Calegari et al. (2017) (11.8 to $\left.235.6 \mu \mathrm{mol} \mathrm{TEAC.g}{ }^{-1}\right)$, using the DPPH method. Calegari et al. (2017) also reported values ranging

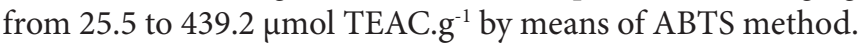

For the antioxidant capacity of propolis extracts determined by FRAP method, the published data were greater than those showed in the present study. Andrade et al. (2017) found mean values of $604.20 \mu \mathrm{mol} \mathrm{TEAC.g}{ }^{-1}$ in ethanolic extract of green propolis from Brazilian Northeast. This is explained by the fact that the capacity of water to extract flavonoids was substantially lower. When the extraction is performed using polar organic solvents such as methanol or ethanol, higher quantity of phenols, hydroxylated flavonoids and other polar compounds was extracted.

\subsection{Red fruit juice formulations supplemented with green propolis extract}

The addition of aqueous extract of green propolis improved the total phenolic and flavonoid content (Table 1) and the antioxidant capacity (Table 2) of the red fruit juice.

The total phenolic values of the formulations varied from 373 to $503 \mathrm{mg} \mathrm{GAE} .100 \mathrm{~g}^{-1}$ red fruit juice, being these values proportional to the added propolis concentration, as expected. The formulations F1, F2, and F3 showed an increase in the phenolic content of $41.8 ; 67.7$ and $91.2 \%$ respectively, compared with the control. This increment was statistically different ( $p<0.05)$, demonstrating the effectiveness of adding of the aqueous green propolis extract to the red fruit juice, in terms of total phenolic content.

Table 1. Total phenolic and flavonoid content in red fruit juice formulations supplemented with propolis

\begin{tabular}{cccc}
\hline \multirow{2}{*}{ Sample } & Total phenolics $^{\star}$ & & Total flavonoids $^{\star *}$ \\
\cline { 2 - 2 } & $\left(\mathrm{mg} \mathrm{GAE}_{\left.100 \mathrm{~g}^{-1}\right)}\right.$ & & $\left(\mathrm{mg} \mathrm{QE}_{\left.100 \mathrm{~g}^{-1}\right)}\right.$ \\
\hline Control & $263 \pm 0.03^{\mathrm{a}}$ & & ND \\
$\mathrm{F}_{1}$ & $373 \pm 0.03^{\mathrm{b} * * *}$ & & $14 \pm 0.01^{\mathrm{a}}$ \\
$\mathrm{F}_{2}$ & $441 \pm 0.02^{\mathrm{c} * *}$ & & $18 \pm 0.01^{\mathrm{b}}$ \\
$\mathrm{F}_{3}$ & $503 \pm 0.03^{\mathrm{d} * * *}$ & $22 \pm 0.00^{\mathrm{c}}$ \\
\hline
\end{tabular}

${ }^{*}$ Mean \pm standard deviation of galic acid (GA) equivalent in mg per 100 grams of sample $\left(\mathrm{mg} \mathrm{GAE} .100 \mathrm{~g}^{-1}\right) ;{ }^{* *}$ Mean \pm standard deviation of quercetin equivalent (QE) in $\mathrm{mg}$ per 100 grams of sample $\left(\mathrm{mg} \mathrm{QE} .100 \mathrm{~g}^{-1}\right)$; Different letters in the columns show a significant difference between them, using the Tukey test at $5 \%$ probability. Significant comparisons by the Dunnet test $(\mathrm{p}<0.05)$ between the control and the formulations are indicated por $* * * . \mathrm{ND}=$ not detected in the assay conditions. Control $=$ not supplemented red fruit juice. Final concentration of propolis: $\mathrm{F} 1=3.1 \mathrm{mg} \cdot \mathrm{mL}^{-1}, \mathrm{~F} 2=4.6 \mathrm{mg} \cdot \mathrm{mL}^{-1}$ and F3 $=6.1 \mathrm{mg} \cdot \mathrm{mL}^{-1}$.
The total flavonoid content was not detected in the used test conditions. However, after addition of aqueous extract of green propolis, the red fruit juice shown a total flavonoids content that varied from 14 to $22 \mathrm{mg} \mathrm{QE} \cdot 100 \mathrm{~g}^{-1}$ (Table 1). Thus, the phenolic content values also significantly increased after addition of aqueous extract of green propolis. The results presented in Table 1 are representative of the potential of aqueous green propolis extracts as a food supplement.

The efficiency of the use of propolis as a food additive was previously reported by Osés et al. (2016), that determined total phenolic (140 to $200 \mathrm{mg} \mathrm{GAE} .100 \mathrm{~g}^{-1}$ ) and total flavonoids (2.5 to $10 \mathrm{mg} \mathrm{QE.} 100 \mathrm{~g}^{-1}$ ) in honey supplemented with 0.1 to $0.5 \%$ of propolis. In the same year, Juszczak et al. (2016) also determined the content of total phenolic (114.82 mg GAE. $\left.100 \mathrm{~g}^{-1}\right)$ and total flavonoids (15.96 mg QE.100 $\mathrm{g}^{-1}$ ) in honey supplemented with propolis. The red fruit juices elaborated in this work, containing propolis varying from 0.31 to $0.61 \%$, presented values from 373 to $484 \mathrm{mg} \mathrm{GAE} 100 \mathrm{~g}^{-1}$ and 14 to $21 \mathrm{mg} \mathrm{QE} 100 \mathrm{~g}^{-1}$, and therefore higher than the above-mentioned honey products supplemented with propolis.

The results obtained for the antioxidant capacity show that the three supplemented red fruit juice formulations differed statistically from the control (Table 2).

The antioxidant capacity of red fruit juice control determined through the ABTS method, was $462.84 \mu \mathrm{mol}$ TEAC. $100 \mathrm{~g}^{-1}$. For the formulations F1 to F3, these values varied from 1119.15 to $1706.71 \mu \mathrm{mol} \mathrm{TEAC.} 100 \mathrm{~g}^{-1}$ (Table 2). The data representing an antioxidant capacity enhancement of at least $240 \%$ in the formulations. These increment values were higher than those reported by Osés et al. (2016), who found 150 to $1200 \mu \mathrm{mol}$ TEAC. $100 \mathrm{~g}^{-1}$ for honeys after the addition of propolis, using the same method and same amount of propolis added.

The antioxidant activity of red fruit juice in a DPPH assay was $221.53 \mu \mathrm{mol} \mathrm{TEAC.} 100 \mathrm{~g}^{-1}$ (Table 2). For formulations supplemented with aqueous extract of green propolis, the antioxidant activity ranged from 775.54 to $1059.92 \mu \mathrm{mol}$ TEAC. $100 \mathrm{~g}^{-1}$.

The mean antioxidant capacity values determined using the FRAP method were higher. However, the results obtained by means of this method were those with the least difference between the control (1057.24 $\mu$ mol TEAC. $\left.100 \mathrm{~g}^{-1}\right)$ and the formulations (1353.05 to $1926.74 \mu \mathrm{mol}$ TEAC. $100 \mathrm{~g}^{-1}$ ) (Table 2). In honey supplemented with propolis, Osés et al. (2016) found antioxidant activity varying from 131.6 to $470.0 \mu \mathrm{mol}$ TEAC. $100 \mathrm{~g}^{-1}$.

Table 2. Antioxidant capacity of red fruit juice formulations supplemented with propolis, determined by ABTS, DPPH and FRAP methods

\begin{tabular}{|c|c|c|c|}
\hline \multirow{2}{*}{ Formulation } & ABTS & $\mathrm{DPPH}$ & FRAP \\
\hline & $\left(\mu \mathrm{mol}\right.$ TEAC. $\left.100 \mathrm{~g}^{-1}\right)$ & $\left(\mu \mathrm{mol}\right.$ TEAC. $\left.100 \mathrm{~g}^{-1}\right)$ & $\left(\mu \mathrm{mol}\right.$ TEAC. $\left.100 \mathrm{~g}^{-1}\right)$ \\
\hline Control & $462.84 \pm 0.05^{\mathrm{a}}$ & $221.53 \pm 0.05^{\mathrm{a}}$ & $1057.24 \pm 0.02^{\mathrm{a}}$ \\
\hline $\mathrm{F}_{1}$ & $1119.15 \pm 0.09^{b * * *}$ & $775.54 \pm 0.09^{\mathrm{b} * * *}$ & $1353.05 \pm 0.04^{\mathrm{b} * * *}$ \\
\hline $\mathrm{F}_{2}$ & $1369.18 \pm 0.05^{c * * *}$ & $899.18 \pm 0.05^{c * * *}$ & $1698.80 \pm 0.03^{c \star * \star}$ \\
\hline $\mathrm{F}_{3}$ & $1706.71 \pm 0.06^{\mathrm{d} * * *}$ & $1059.92 \pm 0.06^{\mathrm{d} * * *}$ & $1926.74 \pm 0.03^{\mathrm{d} * * *}$ \\
\hline
\end{tabular}

Results are expressed as the mean \pm standard deviation $\mu$ mol TEAC. $100 \mathrm{~g}^{-1}$ red fruit juice. Different letters in the columns show a significant difference between them, using the Tukey test at $5 \%$ probability. Significant comparisons by the Dunnet test $(\mathrm{p}<0.05)$ between the control and the formulations are indicated by ${ }^{* * *}$. Control $=$ not supplemented red fruit juice. Final concentration of propolis: $\mathrm{F} 1=3.1 \mathrm{mg} \cdot \mathrm{mL}^{-1}, \mathrm{~F} 2=4.6 \mathrm{mg} \cdot \mathrm{mL}^{-1}$ and $\mathrm{F} 3=6.1 \mathrm{mg} \cdot \mathrm{mL}^{-1}$. 
The data set obtained by the DPPH, ABTS and FRAP methods (Table 2) shown a significant increase in the antioxidant capacity in the red fruit formulations in relation to the control. The antioxidant activity increment was proportional to the concentration of aqueous green propolis extracts added to the juice. Among the three methods used, the DPPH method was the most significant to demonstrate the increase in antioxidant activity associated with the addition of the aqueous propolis extract to the red fruit juice.

\subsection{Sensorial analysis}

Each formulation of red fruit juice supplemented with aqueous propolis extract was evaluated in terms of sensory parameters and purchase intention. In the first session of sensory analysis did not observed significant difference $(p>0.05)$ between the appearance, taste, aroma, colour and global impression of the three formulations. Based on a 9-point hedonic scale, which ranges from extremely dislike (1) to extremely like (9), the values obtained for the formulations ranged from 6.6 to 7.1 (Table 3).

According to the paired t test $(\mathrm{p}>0.05)$, the sensory evaluation obtained after presenting information about the benefits of red fruits juices and of propolis for human health did not show significative changes in the scores. To better understanding of the results, the global impression scores of the first and second session were grouped in relation to the evaluated attributes referring to the 9-point hedonic scale. Thus, the data obtained using this scale were distributed in three classes: approval, indifferent and rejection. The approval class was equivalent to the 9-point hedonic scores from 6 ("slightly liked") to 9 ("extremely liked"), the indifferent class, equivalent to a score of 5 ("I didn't like or dislike"), and the rejection class was equivalent to scores from 1 ("I really disliked") to 4 ("I disliked slightly"). The results using this frequency analysis showed that the red fruit juice formulations shown acceptance rates ranging from 85.75 to $90.2 \%$ (Figure 2). This high frequency of positive scores indicated that the red fruit juice supplemented with propolis was well accepted by the consumers.

No significant increase was observed in the average scores for any of the attributes and formulations (Figure 2), after the consumers had received the functional claims of the product. A possible explanation for this result is the fact that the red fruit juice supplemented with propolis has been well accepted since the first sensory evaluation test. It was observed that with the

Table 3. Results of the first sensory evaluation session of red fruit juice formulations supplemented with aqueous extract of green propolis, based on a 9-point hedonic scale

\begin{tabular}{ccccc}
\hline Attributes & F1 & F2 & F3 & P-value \\
\hline Appearance & $7.1 \pm 1.4^{\mathrm{a}}$ & $7.0 \pm 1.3^{\mathrm{a}}$ & $6.7 \pm 1.5^{\mathrm{a}}$ & 0.0707 \\
Taste & $6.6 \pm 1.7^{\mathrm{a}}$ & $6.7 \pm 1.7^{\mathrm{a}}$ & $7.0 \pm 1.7^{\mathrm{a}}$ & 0.2208 \\
Aroma & $6.8 \pm 1.7^{\mathrm{a}}$ & $6.8 \pm 1.5^{\mathrm{a}}$ & $7.1 \pm 1.6^{\mathrm{a}}$ & 0.3459 \\
Colour & $7.0 \pm 1.5^{\mathrm{a}}$ & $6.9 \pm 1.5^{\mathrm{a}}$ & $6.6 \pm 1.7^{\mathrm{a}}$ & 0.2148 \\
Global impression & $7.0 \pm 1.3^{\mathrm{a}}$ & $6.9 \pm 1.4^{\mathrm{a}}$ & $7.1 \pm 1.5^{\mathrm{a}}$ & 0.6213 \\
\hline
\end{tabular}

Data are expressed as mean \pm standard deviation. Means followed by equal letters on the same line do not differ statistically through the Tukey test at $5 \%$ probability. Concentration of propolis: $\mathrm{F} 1=3.1 \mathrm{mg} \cdot \mathrm{mL}^{-1}, \mathrm{~F} 2=4.6 \mathrm{mg} \cdot \mathrm{mL}^{-1}$ and $\mathrm{F} 3=6.1 \mathrm{mg} \cdot \mathrm{mL}^{-1}$. propolis supplementation and polyalcohol (xylitol) addition, in this work, it was possible to improve bioactive properties of red juice, a commercial product already well accepted by consumers.

There are still few studies in the literature addressing the use of propolis as a supplement in food products. The greatest obstacle to this non-supplementation of food is directly associated with the taste and aroma of propolis. In some cases, these characteristics are responsible for the total refusal by the consumer of foods to which an extract of propolis can be added (Pobiega et al., 2019). For this reason, the formulations of red fruit juice supplemented with aqueous propolis extract made in this work were aimed at offering a drink containing propolis, which was well accepted sensorially.

Some researchers showed that propolis concentrations $<0.5 \%$ in juices, such as acerola (Neves \& Lima, 2011), orange
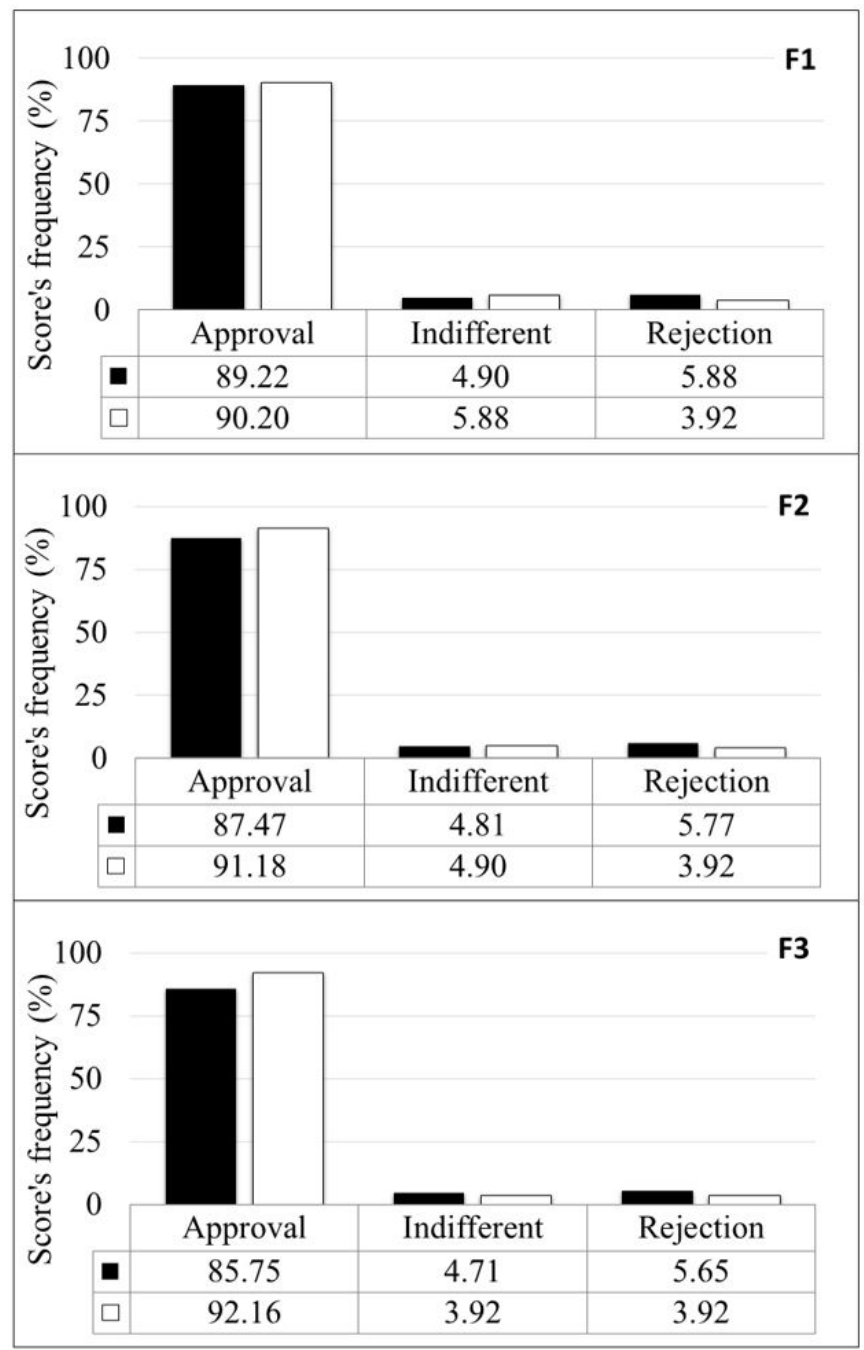

Figure 2: Frequency of global impression for the red fruits juice supplemented with aqueous extract of green propolis. $\bullet=$ Blind test, made without information about health benefits of red fruit juice and propolis. $\square=$ Evaluation made after information about health benefits. The 9-point hedonic scale was distributed as: Approval (scores 6 to 9); Indifferent (score 5) and Rejection (scores 1 to 4). Concentration of propolis: $\mathrm{F} 1=3.1 \mathrm{mg} \cdot \mathrm{mL}^{-1}, \mathrm{~F} 2=4.6 \mathrm{mg} \cdot \mathrm{mL}^{-1}$ and $\mathrm{F} 3=6.1 \mathrm{mg} \cdot \mathrm{mL}^{-1}$. 
(Luis-Villaroya et al., 2015), apple (Yang et al., 2017), and also in honey (Juszczak et al., 2016; Osés et al., 2016) were well accepted by the consumers. However, these products have been developed containing high levels of sugar in their composition, different from the formulations prepared in this work, which do not have cane sugar, but rather the sugars that are naturally found in the fruits that make up the natural fruit juice studied. In addition, to help improve the taste of red fruit juice formulations, xylitol sweetener has been added to improve the final taste of the product and benefit people with restricted dietary sugar, such as diabetics.

In some food industries, propolis extracts are added as preservative in beverages, to maintain postharvest quality of fruits during its storage, and also in vegetables, eggs, meat, fish and its derivatives (Bankova et al., 2016). Pobiega et al. (2019) enlarged the products enrolled in the Bankova's review and discoursed about the influence of propolis on sensory properties of food. In most cases the taste and aroma caused by the addition of propolis has been associated with consumer rejection of the food.

Due to the high frequency of global impression (Figure 2), an evaluation about the purchase intention of the red fruits juice supplemented with aqueous extract of green propolis was carried out. Among the three formulations, F3 was the one with the best result of purchase intention (Table 4). Scores 4 and 5 were used as a reference for positive purchase intention, covered $64.75 \%$ of participants' acceptance.

In the second session, the purchase intention was evaluated after information about the health benefits of both red fruits juice and propolis were presented. Then, the proportion of tasters who would buy the product increased by $21 \%$, and the proportion of those who were indifferent or who would not buy decreased (Table 4).

Luis-Villaroya et al. (2015) reported that apple juice containing $0.2 \mathrm{mg} \cdot \mathrm{mL}^{-1}$ of propolis were less appreciated by consumers compared with 0.05 and $0.1 \mathrm{mg} \cdot \mathrm{mL}^{-1}$, although after knowing the content of propolis in each sample the buying intention did not decrease, and apple juice with $0.05 \mathrm{mg} / \mathrm{mL}$ of propolis buying intention increased by $22 \%$. The results obtained in the present work corroborates data reported by Luis-Villaroya et al. (2015). These results confirm that knowledge about the health benefits reported to consumers positively influenced its intention to purchase juices and other foods supplemented with propolis. Thus, the consumers would be willing to buy and consume the red fruit juice supplemented with propolis, due to its new set of sensorial and functional properties.

Table 4. Distribution formulations of red fruit juices supplemented with aqueous extract of green propolis of purchase intention between consumers in different sessions of sensorial analysis

\begin{tabular}{ccccccccc}
\hline \multirow{2}{*}{ Formulations } & \multicolumn{2}{c}{ Would not buy } & & \multicolumn{2}{c}{ Indifferent } & & \multicolumn{2}{c}{ Would buy } \\
\cline { 2 - 3 } & S1 & S2 & & S1 & S2 & & S1 & S2 \\
\hline F1 & 17.65 & 13.72 & & 33.33 & 19.61 & & 49.02 & 66.67 \\
F2 & 22.55 & 18.63 & & 26.47 & 18.63 & & 50.98 & 62.75 \\
F3 & 13.72 & 9.8 & & 23.53 & 21.57 & & 62.75 & 68.63 \\
\hline
\end{tabular}

$\mathrm{S} 1=$ Session 1 , test without information. $\mathrm{S} 2=$ Session 2 , test with information about health benefits. Formulations: $\mathrm{F} 1=3.1 \mathrm{mg} \cdot \mathrm{mL}^{-1}, \mathrm{~F} 2=4.6 \mathrm{mg} \cdot \mathrm{mL}^{-1}$ and $\mathrm{F} 3=6.1 \mathrm{mg} \cdot \mathrm{mL}^{-1}$.

\section{Conclusion}

The addition of propolis to red fruit juice increased the content of total phenolic compounds and flavonoids, enhanced the antioxidant activity of the final product as assessed by radical scavenging DPPH and ABTS and FRAP methods, however, had no produce negative effect on consumer taste. All red fruit juice formulations containing propolis were well accepted by the volunteer consumers. Formulation F3 $\left(6.1 \mathrm{mg} \cdot \mathrm{mL}^{-1}\right)$ showed the best results. A new, sugar-free drink with pleasurable sensory and functional properties, combined with health benefits, has been obtained.

\section{Acknowledgement}

The authors thank to Conselho Nacional de Desenvolvimento Científico e Tecnológico - CNPq (Project n 421544/2016-3) and Fundação de Amparo à Pesquisa do Estado de Minas Gerais FAPEMIG (Grant for GAL).

\section{References}

Altemimi, A., Lakhssassi, N., Baharlouei, A., Watson, D. G., \& Lightfoot, D. A. (2017). Phytochemicals: Extraction, isolation, and identification of bioactive compounds from plant extracts. Plants, 6(4), 42. http:// dx.doi.org/10.3390/plants6040042. PMid:28937585.

Alves, E., \& Kubota, E. H. (2013). Conteúdo de fenólicos, flavonoides totais e atividade antioxidante de amostras de própolis comerciais. Revista de Ciências Farmacêuticas Básica e Aplicada, 34(1), 37-41.

Andrade, J. K. S., Denadai, M., de Oliveira, C. S., Nunes, M. L., \& Narain, N. (2017). Evaluation of bioactive compounds potential and antioxidant activity of brown, green and red propolis from Brazilian northeast region. Food Research International, 101, 129-138. http:// dx.doi.org/10.1016/j.foodres.2017.08.066. PMid:28941675.

Arruda, C., Pena Ribeiro, V., Oliveira Almeida, M., Aldana Mejía, J. A., Casoti, R., \& Kenupp Bastos, J. (2020). Effect of light, oxygen and temperature on the stability of artepillin $\mathrm{C}$ and p-coumaric acid from Brazilian green propolis. Journal of Pharmaceutical and Biomedical Analysis, 178, 112922. http://dx.doi.org/10.1016/j.jpba.2019.112922. PMid:31679843.

Bankova, V., Popova, M., \& Trusheva, B. (2016). New emerging fields of application of propolis. Macedonian Journal of Chemistry and Chemical Engineering, 35(1), 1-11. http://dx.doi.org/10.20450/ mjcce.2016.864.

Bermúdez-Soto, M. J., \& Tomás-Barberán, F. A. (2004). Evaluation of commercial red fruit juice concentrates as ingredients for antioxidant functional juices. European Food Research and Technology, 219(2), 133-141. http://dx.doi.org/10.1007/s00217-004-0940-3.

Bezerra, A. S., Stankievicz, S. A., Kaufmann, A. I., Machado, A. A. R., \& Uczay, J. (2017). Composição nutricional e atividade antioxidante de plantas alimentícias não convencionais da região Sul do Brasil. Arquivos Brasileiros de Alimentação, 1(1), 182-188.

Bittencourt, M. L., Ribeiro, P. R., Franco, R. L., Hilhorst, H. W., de Castro, R. D., \& Fernandez, L. G. (2015). Metabolite profiling, antioxidant and antibacterial activities of Brazilian propolis: Use of correlation and multivariate analyses to identify potential bioactive compounds. Food Research International, 76(Pt 3), 449-457. http:// dx.doi.org/10.1016/j.foodres.2015.07.008. PMid:28455025.

Calegari, M. A., Prasniewski, A., Silva, C. D., Sado, R. Y., Maia, F., Tonial, L., \& Oldoni, T. L. (2017). Propolis from Southwest of Parana produced by selected bees: Influence of seasonality and 
food supplementation on antioxidant activity and phenolic profile. Anais da Academia Brasileira de Ciências, 89(1), 45-55. http://dx.doi. org/10.1590/0001-3765201620160499. PMid:28177054.

Costa, N. M. B., \& Rosa, C. O. B. (2016). Alimentos funcionais: componentes bioativos e efeitos fisiológicos. Rio de Janeiro: Editora Rubio.

da Costa, L. A. M. A., Barbosa, S. R., Holanda, G. C., \& Flach, A. (2016). Teor de fenólicos e atividade antioxidante de própolis em áreas de floresta e savana de Roraima. RCT-Revista de Ciência e Tecnologia, 2(3), 1-11.

da Cruz Almeida, E. T., da Silva, M. C. D., Oliveira, J. M. S., Kamiya, R. U., \& Arruda, R. E. S., Vieira, D. A., Silva, V. C., Escodro, P. B., Basílio-Júnior, I. D., \& do Nascimento, T. G. (2017). Chemical and microbiological characterization of tinctures and microcapsules loaded with Brazilian red propolis extract. Journal of Pharmaceutical Analysis, 7(5), 280-287. https://doi.org/https://doi.org/10.1016/j. jpha.2017.03.004.

de Andrade Lopes, W. M., Coutinho, D. J. G., Marinho, G. A., de Lima, J. L., \& de Andrade Lopes, W. (2020). Atuação do nutricionista na prevenção e controle da hipertensão arterial sistêmica e do diabetes mellitus/Nutritionist activity in the prevention and control of systemic arterial hypertension and diabetes mellitus. Brazilian Journal of Health Review, 3(1), 308-324. http://dx.doi.org/10.34119/bjhrv3n1-023.

de Figueiredo, S. M., Nogueira-Machado, A., Almeida, B. M., Abreu, S. R., de Abreu, J. A., Filho, S. A., Binda, N. S., \& Caligiorne, R. B. (2014). Immunomodulatory properties of green propolis. Recent Patents on Endocrine, Metabolic \& Immune Drug Discovery, 8(2), 85-94. http://dx.doi.org/10.2174/1872214808666140619115319. PMid:24948024.

Dranca, F., \& Oroian, M. (2016). Optimization of ultrasound-assisted extraction of total monomeric anthocyanin (TMA) and total phenolic content (TPC) from eggplant (Solanum melongena L.) peel. Ultrasonics Sonochemistry, 31, 637-646. http://dx.doi.org/10.1016/j. ultsonch.2015.11.008. PMid:26701808.

Ferreira, J. M., \& Negri, G. (2018). Composição química e atividade biológica das própolis brasileiras: verde e vermelha. ACTA Apicola Brasilica, 6(1), 6-15.

Ferreira, T. C., Ramos, R. J., Dutra, R. L., \& Assini, F. L. (2019). Ação de um bolo funcional e um convencional na glicemia pós-prandial de docentes. Revista Eletrônica Estácio Saúde, 8(2), 31-38.

Franz, G. M., Ferreira, J. O., Longo, L., Loureiro, E. M., Mendonça, J. D. C., Bárbara, K. G., \& Galbiati, C.. (2018). Análise polínica e compostos fenólicos de mel e própolis do Pantanal, Mato Grosso, Brasil. Revista Ibero-Americana de Ciências Ambientais, 9(1), 13-25. http://dx.doi.org/10.6008/SPC2179-6858.2018.001.0002.

Galeotti, F., Maccari, F., Fachini, A., \& Volpi, N. (2018). Chemical composition and antioxidant activity of propolis prepared in different forms and in different solvents useful for finished products. Foods, 7(3), 41. http://dx.doi.org/10.3390/foods7030041. PMid:29562665.

Gregolin, F. S., Bonaldo, S. M., Sinhorin, A. P., Banderó, J. L., \& Wobeto, C. (2019). The in vitro control of Fusarium proliferatum by propolis ethanolic extracts. Revista de Ciências Agrárias (Belém), 42(2), 456-463.

Hochheim, S., Guedes, A., Faccin-Galhardi, L., Rechenchoski, D. Z., Nozawa, C., Linhares, R. E., Filho, H. H. S., Rau, M., Siebert, D. A., Micke, G., \& Cordova, C. M. M. (2019). Determination of phenolic profile by HPLC-ESI-MS/MS, antioxidant activity, in vitro cytotoxicity and anti-herpetic activity of propolis from the Brazilian native bee Melipona quadrifasciata. Revista Brasileira de Farmacognosia, 29(3), 339-350. http://dx.doi.org/10.1016/j.bjp.2018.12.010.

Jansen-Alves, C., Fernandes, K. F., Crizel-Cardozo, M. M., Krumreich, F. D., Borges, C. D., \& Zambiazi, R. C. (2018). Microencapsulation of propolis in protein matrix using spray drying for application in food systems. Food and Bioprocess Technology, 11(7), 1422-1436. http://dx.doi.org/10.1007/s11947-018-2115-4.

Juszczak, L., Gałkowska, D., Ostrowska, M., \& Socha, R. (2016). Antioxidant activity of honey supplemented with bee products. Natural Product Research, 30(12), 1436-1439. http://dx.doi.org/10 .1080/14786419.2015.1057582. PMid:26153086.

Kubota, M., Ishikawa, C., Sugiyama, Y., Fukumoto, S., Miyagi, T., \& Kumazawa, S. (2012). Anthocyanins from the fruits of Rubus croceacanthus and Rubus sieboldii, wild berry plants from Okinawa, Japan. Journal of Food Composition and Analysis, 28(2), 179-182. http://dx.doi.org/10.1016/j.jfca.2012.09.002.

Lim, J. (2011). Hedonic scaling: a review of methods and theory. Food Quality and Preference, 22(8), 733-747. http://dx.doi.org/10.1016/j. foodqual.2011.05.008.

Luis-Villaroya, A., Espina, L., García-Gonzalo, D., Bayarri, S., Pérez, C., \& Pagán, R. (2015). Bioactive properties of a propolis-based dietary supplement and its use in combination with mild heat for apple juice preservation. International Journal of Food Microbiology, 205, 90-97. http://dx.doi.org/10.1016/j.ijfoodmicro.2015.03.020. PMid:25897992.

Lustosa, S. R., Galindo, A. B., Nunes, L. C. C., Randau, K. P., \& Rolim, P. J. No.(2008). Própolis: atualizações sobre a química e a farmacologia. Revista Brasileira de Farmacognosia, 18(3), 447-454. http://dx.doi. org/10.1590/S0102-695X2008000300020.

Manubolu, M., Goodla, L., Ravilla, S., Thanasekaran, J., Dutta, P., Malmlöf, K., \& Obulum, V. R. (2014). Protective effect of Actiniopteris radiata (Sw.) Link. against $\mathrm{CCl} 4$ induced oxidative stress in albino rats. Journal of Ethnopharmacology, 153(3), 744-752. http://dx.doi. org/10.1016/j.jep.2014.03.040. PMid:24680994.

Mello, B. C., \& Hubinger, M. D. (2012). Antioxidant activity and polyphenol contents in Brazilian green propolis extracts prepared with the use of ethanol and water as solvents in different $\mathrm{pH}$ values. International Journal of Food Science \& Technology, 47(12), 25102518. http://dx.doi.org/10.1111/j.1365-2621.2012.03129.x.

Neves, M. d., \& Lima, V. (2011). Avaliação sensorial e caracterização físico-química de néctar de acerola adicionado de extrato comercial de própolis Evaluation sensory and characterization physical chemistry of nectar acerola added of extract commercial propolis. Alimentos e Nutrição Araraquara, 21(3), 399-406.

Nunes, L. C. C., Galindo, A. B., Deus, A. S. O. d., Rufino, D. A., Randau, K. P., Xavier, H. S., Citó, A. M. G. L., \& Rolim, P. J. No. (2009). Seasonal variability of red propolis constituents and brine shrimp bioassay. Revista Brasileira de Farmacognosia, 19(2B), 524-529.

Osés, S., Pascual-Maté, A., Fernández-Muiño, M., López-Díaz, T., \& Sancho, M. (2016). Bioactive properties of honey with propolis. Food Chemistry, 196, 1215-1223. http://dx.doi.org/10.1016/j. foodchem.2015.10.050. PMid:26593609.

Pobiega, K., Kraśniewska, K., \& Gniewosz, M. (2019). Application of propolis in antimicrobial and antioxidative protection of food quality-A review. Trends in Food Science \& Technology, 83, 53-62. http://dx.doi.org/10.1016/j.tifs.2018.11.007.

Re, R., Pellegrini, N., Proteggente, A., Pannala, A., Yang, M., \& RiceEvans, C. (1999). Antioxidant activity applying an improved ABTS radical cation decolorization assay. Free Radical Biology \& Medicine, 26(9-10), 1231-1237. http://dx.doi.org/10.1016/S0891-5849(98)003153. PMid:10381194.

Rufino, M., Alves, R. E., De Brito, E., De Morais, S., Sampaio, C. G., Pérez-Jiménez, J., \& Saura-Calixto, F. D. (2006). Metodologia científica: determinação da atividade antioxidante total em frutas pelo método de redução do ferro (FRAP) (Comunicado Técnico - INFOTECA-E). Fortaleza: Embrapa Agroindústria Tropical. 
Rufino, M., Alves, R. E., de Brito, E. S., de Morais, S. M., Sampaio, C. G., Pérez-Jimenez, J., \& Saura-Calixto, F. D. (2007). Metodologia científica: determinação da atividade antioxidante total em frutas pela captura do radical livre DPPH. (Comunicado Técnico - INFOTECA-E). Fortaleza: Embrapa Agroindústria Tropical.

Shahinozzaman, M., Basak, B., Emran, R., Rozario, P., \& Obanda, D. (2020). Artepillin C: A comprehensive review of its chemistry, bioavailability, and pharmacological properties. Fitoterapia, 147, 104775. http://dx.doi.org/10.1016/j.fitote.2020.104775. PMid:33152464.

Silva, A. C. C., Silva, N. A., Pereira, M. C. S., \& Vassimon, H. (2016). Alimentos contendo ingredientes funcionais em sua formulação: revisão de artigos publicados em revistas brasileiras. Revista Conexão Ciência, 11(2), 133-144. http://dx.doi.org/10.24862/cco.v11i2.429.

Singleton, V. L., \& Rossi, J. A. (1965). Colorimetry of total phenolics with phosphomolybdic-phosphotungstic acid reagents. American Journal of Enology and Viticulture, 16(3), 144-158.

Sousa, J. P. L. M., Pires, L. O., Prudêncio, E. R., Santos, R. F., Sant'Ana, L. D., Ferreira, D. A. S., \& Castro, R. N. (2019). Estudo Químico e Potencial Antimicrobiano da Própolis Brasileira Produzida por Diferentes Espécies de Abelhas. Revista Virtual de Química, 11(5), 1480-1497.

Stringueta, P. C., Amaral, M., Pereira Brumano, L., Santana Pereira, M., \& Oliveira Pinto, M. (2012). Public health policies and functional property claims for food in Brazil. In A. A. Eissa (Eds.), Structure and function of food engineering (pp. 307-336). London: IntechOpen Limited.

Toreti, V. C., Sato, H. H., Pastore, G. M., \& Park, Y. K. (2013). Recent progress of propolis for its biological and chemical compositions and its botanical origin. Evidence-Based Complementary and Alternative Medicine, 2013, 697390. http://dx.doi.org/10.1155/2013/697390. PMid:23737843.

Vetrani, C., Costabile, G., Di Marino, L., \& Rivellese, A. (2013). Nutrition and oxidative stress: a systematic review of human studies. International Journal of Food Sciences and Nutrition, 64(3), 312-326. http://dx.doi.org/10.3109/09637486.2012.738651. PMid:23121370.

Vidal, A. M., Dias, D. O., Martins, E. S. M., Oliveira, R. S., Nascimento, R. M. S., \& da Silva Correia, M. G. (2012). A ingestão de alimentos funcionais e sua contribuição para a diminuição da incidência de doenças. Caderno de Graduação-Ciências Biológicas e da SaúdeUNIT-SERGIPE, 1(1), 43-52.

Vidigal, M. C., Minim, V. P., Carvalho, N. B., Milagres, M. P., \& Gonçalves, A. C. (2011). Effect of a health claim on consumer acceptance of exotic Brazilian fruit juices: Açaí (Euterpe oleracea Mart.), Camu-camu (Myrciaria dubia), Cajá (Spondias lutea L.) and Umbu (Spondias tuberosa Arruda). Food Research International, 44(7), 1988-1996. http://dx.doi.org/10.1016/j.foodres.2010.11.028.

Woisky, R. G., \& Salatino, A. (1998). Analysis of propolis: some parameters and procedures for chemical quality control. Journal of Apicultural Research, 37(2), 99-105. http://dx.doi.org/10.1080/0 0218839.1998.11100961.

Yang, W., Wu, Z., Huang, Z. Y., \& Miao, X. (2017). Preservation of orange juice using propolis. Journal of Food Science and Technology, 54(11), 3375-3383. http://dx.doi.org/10.1007/s13197-017-2754-x. PMid:29051632. 